\title{
Drama Komedi Parodi Karya N. Riantiarno Kajian Resepsi Intertekstual
}

\author{
Chairul Anwar \\ Jurusan Teater, Fakultas Seni Pertunjukan, Institut Seni Indonesia Yogyakarta \\ chairulanwarisiyk@gmail.com
}

\begin{abstract}
Penelitian ini bertujuan menganalisis drama komedi parodi Konglomerat Burisrawa dan Semar Gugat karya N. Riantiarno. Kedua drama tersebut adalah respon terhadap pemerintahan rezim Orde Baru yang bertentangan dengan demokrasi. Kedua drama tesebut adalah parodi dari mitos manunggaling kawula Gusti dalam lakon wayang Sembadra Larung dan Semar Gugat yang menjadi hipogramnya. Pengumpulan data dilakukan melalui studi pustaka. Metode analisis yang digunakan dalam penelitian ini adalah metode analisis isi atau content analysis. Data yang terkumpul dianalisis menggunakan teori resepsi intertekstual dan konsep ironi serta teknik permutasi atau teknik replacement, yaitu teknik perpindahan atau pertukaran tempat dari drama komedi parodi Barat. Hasil penelitian menunjukkan bahwa kesatuan penokohan Arjuna, Srikandi, dan Semar dalam lakon wayang sebagai penokohan simbolis yang melestarikan mitos manunggaling kawula Gusti bertukar tempat menjadi penokohan parodi yang mengalami split karakter atau pribadi terbelah, sehingga kesatuan mitos tersebut mengalami keterbelahan dan hanya menjadi parodi mitos. Hal ini bertentangan dengan demokrasi.
\end{abstract}

Kata kunci : konglomerat burisrawa dan semar gugat, resepsi intertekstual, parodi mitos

\section{Comedy Drama Parody by N. Riantiarno Study of Intertextual Reception}

This study aims to analyze the comedy drama parody of Konglomerat Burisrawa and Semar Gugat by N. Riantiarno. The two dramas were a response to the government of the New Order regime which was contrary to democracy. The two dramas are a parody of the myth of the manunggaling kawula Gusti in the Sembadra Larung and Semar Gugat puppets which became the hipogram (background). Data collection is done through library research. The analytical method used in this study is the method of content analysis. The collected data was analyzed using intertextual reception theory and irony concepts as well as the permutation techniques or the replacement techniques, that is, the technique of displacement or exchange of places from Western comedy drama parody. The results showed that the characterization of Arjuna, Srikandi, and Semar in puppets play as symbolic characterizations that preserved the myth of the manunggaling kuwula Gusti which changed into a characterization of parodies that experienced split characters, so that the unity of myths became a parody of myths. This is contrary to democracy.

Keywords : burisrawa conglomerates and semar gugat, intertextual reception, parody of myth

Proses Review : 1 - 20 Agustus 2019, Dinyatakan Lolos: 22 Agustus 2019 


\section{PENDAHULUAN}

Drama komedi parodi karya N. Riantiarno (selajutnya disebut Nano) mampu mengangkat gagasan protes dengan menggunakan bentuk pengungkapan yang canggih dan elegan, tetapi halus menyindir praktik penyelenggaraan pemerintahan Orde Baru di bawah kepemimpinan presiden Soeharto yang bertentangan dengan demokrasi. Rezim Orde Baru membiarkan elit di lingkungan terdekatnya menjelma menjadi korporasi atau konglomerasi yang bertentangan dengan demokrasi.

Drama komedi parodi karya Nano yang menjadi objek kajian berikut ini adalah drama Konglomerat Burisrawa (selanjutnya disingkat KB) dan drama Semar Gugat (selanjutnya disingkat $\mathrm{SG}$ ). Ide drama KB dan drama SG ditimba dari sumber lakon wayang Sembadra Larung dan Semar Gugat. Mitos manunggaling kawula Gusti, artinya kesatuan pemimpin dan rakyat yang dikandung lakon-lakon wayang tradisional tersebut adalah simbol demokrasi. Drama KB dan SG selain menimba ide dari sumber lakon-lakon wayang tradisional tersebut, tetapi juga menggali gagasan dari sumber drama komedi parodi Barat. Oleh karena itu, drama KB dan SG menunjukkan pemandangan-pemandangan lucu yang maknanya bertentangan dengan demokrasi. Drama KB dan SG menggali konsep ironi dan metode permutasi atau replacement, yaitu metode pertukaran tempat dari drama komedi parodi Barat. Perpaduan kedua sumber tersebut menghasilkan drama KB dan SG yang menunjukkan bentuk pengungkapan baru yang berbeda dengan sumber aslinya atau karya sebelumnya.

Teeuw (1984: 57, 151) menyatakan bahwa kajian struktural terhadap karya sastra bersifat elit, melepaskan karya sastra itu dari konteks sosial dan meniadakan relevansi kemasyarakatannya. Surheni (2015: 64) menambahkan bahwa karya seni adalah sistem tanda. Oleh karena itu pemaknaan terhadap karya tersebut tergantung kepada konteks tempat di mana sistem simbol tersebut disepakati bersama berdasarkan konvensi. Sementara Iser (1983: 274-275) menyatakan bahwa kajian terhadap karya sastra adalah melakukan konkretisasi, sehingga dapat dikenal "semangat zaman". Junus (1985: 32) menambahkan, konkretisasi yang dilakukan pembaca sebagai peneliti bisa menjelaskan bahwa seorang pengarang mentransformasikan nilai-nilai yang ada pada karya sastra sebelumnya ke dalam karya sastra baru dalam bentuk pengungkapan yang berbeda.

Selanjutnta Junus (1985:35) menyatakan bahwa konkretisasi yang dilakukan oleh pembaca sebagai pengarang karya sastra adalah melalui rekonstruksi dan tidak mungkin dilakukan tanpa imajinasi. Imajinasi pembaca sebagai pengarang karya sastra dimungkinkan melalui keakraban dengan tradisi sastra dan kesanggupan memahami keadaan pada masanya, mungkin juga masa sebelumnya. Imajinasi pembaca sebagai pengarang karya sastra bisa menciptakan karya baru dalam bentuk yang berbeda. Karya baru itu mungkin diungkapkan dengan cara bertentangan, parodi dan demitefikasi.

Nano selaku pembaca dan sekaligus pengarang drama, melalui imajinasinya melakukan rekonstruksi lakon wayang Sembadra Larung dan Semar Gugat. Rekonstruksi yang dilakukan Nano dimungkinkan karena keakrabannya dengan tradisi lakon wayang dan pengalamannya menyadur drama komedi parodi dari Barat. Konkretisasi yang dlakukan Nano adalah menciptakan drama baru, yakni drama KB dan SG dalam bentuk yang berbeda. Drama baru itu diungkapkan dalam bentuk bertentangan, parodi dan demitefikasi.

Fenomena di atas menarik dan penting dijadikan kajian. Topik ini sesuai jika dikaji menggunakan teori resepsi intertektual. Pertama, teori resepsi dari Jauss yang bertolak dari konstruksi yang dibangun atas dasar konsep identitas estetik dan oposisi estetik (Fokkema \& Kunne-Ibsch, 1977: 148-150). Teeuw (1991: 26- 27) menambahkan bahwa konsep identitas estetik atau yang disebut dengan estetika persamaan berkaitan dengan karya sastra yang struktur dan maknanya sudah ditetapkan sebelumnya. Ketentuan struktur dan makna didasarkan pada horizon harapan si pembaca atau penonton yang mengenali kembali struktur dan makna karya sastra yang sudah diakrabinya. Karya drama yang termasuk dalam golongan ini adalah lakon wayang Sembadra Larung dan Semar Gugat yang tradisional. Sementara konsep oposisi estetik adalah bertentangan dengan konsep identitas estetik. Karya sastra yang termasuk golongan semacam ini adalah karya sastra baru dan modern yang struktur dan maknanya belum dikenal atau belum akrab. Oleh karena itu adalah tugas pembaca sebagai peneliti menjelaskan struktur dan makna karya baru tersebut yang bertentangan dengan karya sebelumnya.

Teori resepsi sastra yang digunakan dalam kajian ini bertujuan menjelaskan bagaimana Nano sebagai penulis kreatif menggunakan karya sastra sebelumnya, yakni lakon wayang Sembadra Larung dan Semar Gugat untuk menghasilkan karya drama yang baru, yaitu drama KB dan SG dengan bentuk pengungkapan baru, yakni drama komedi parodi yang struktur dan maknanya bertentangan dengan lakon-lakon wayang yang menjadi hypogram-nya. Pengertian hypogram diambil dari Riffaterre (1978: 81-114) yang berpendapat bahwa hypogram adalah teks sebelumnya yang menjadi contoh, teladan, atau kerangka teks yang baru.

Pendekatan di atas juga didasarkan pada teori intertekstualitas atau hubungan antar teks. Jacques Derrida (dalam Culler: 1981) menyatakan bahwa karya sastra adalah konstruksi intertekstual. Karya sastra dibaca hanya dalam kaitannya dengan teks-teks lain. Tugas pembaca dalam 
memberi makna karya sastra adalah membongkar teks dengan mengembalikannya kepada teks-teks lain. Karya sastra adalah bentuk transformasi dari karya sebelumnya. Bentuk transformasi tersebut dapat berupa pertentangan, oposisi dan paradoks.

Barthes (dalam Young, 1987: 31-32, 39) menyatakan bahwa karya sastra adalah suatu jaringan intertekstual. Karya sastra akan menjadi pengalaman hanya di dalam aktifitas produksi. Karya sastra adalah rekonstruksi dari karya sastra sebelumnya dalam bentuk permutasi atau replacement, yaitu pertukaran atau pemindahan tempat karena suatu kritisisme.

Julia Kristeva (dalam Yudiaryani, 2015: 23) menyatakan bahwa analisis intertekstual terhadap karya sastra didasarkan atas pendapat bahwa karya sastra adalah jejaring atau tenunan yang berasal dari kutipan karya sastra sebelumnya atau kutipan dari teks-teks yang lain. Karya sastra dan teks-teks lain atau tenunan tersebut kemudian memproduksi jejaring atau tenunan baru. Praktik kajian tersebut dapat digambarkan seperti halnya laba-laba yang menenggelamkan dirinya dalam jejaring yang dibuatnya. Kajian intertekstual adalah hipologi. Hypos adalah rajutan, tenunan, jejaring.

Peneliti selaku pembaca dalam kajian ini bertugas membongkar struktur dan memberi makna dengan cara menelusuri tenunan drama KB dan SG. Pembacaan struktur dan makna drama KB dan SG adalah dengan menghubungkan mitos yang melekat pada tokoh-tokoh dalam lakon wayang Sembadra Larung dan Semar Gugat dan konsep drama komedi parodi dari Barat. Peneliti menjelaskan bagaimana drama KB dan SG adalah parodi mitos yang terbentuk karena resepsi intertektual drama tersebut terhadap mitos yang dikandung lakon-lakon wayang yang menjadi hypogram-nya.

Peneliti sebagai pembaca dalam kajian ini menjelaskan bagaimana drama KB dan SG menunjukkan pertentangan makna mitos yang melekat pada tokoh-tokoh lakon wayang Sembadra Larung dan Semar Gugat. Drama KB dan SG dihubungkan dengan konsep ironi dan metode permutasi atau replacement, yaitu pertukaran tempat dari drama komedi parodi Barat. Peneliti menjelaskan bagaimana drama KB dan SG melakukan perpindahan tempat tokoh-tokoh masa lalu dalam lakon-lakon wayang Sembadra Larung dan Semar Gugat yang tradisional menjadi tokoh-tokoh parodi masa kini dalam drama modern yang menunjukkan ironi, sehingga menimbulkan pemandangan-pemandangan lucu

\section{MITOS}

J. van Baal (1987: 39-48) menyatakan, bahwa cerita mitos sudah ada sejak zaman Yunani Kuno. Tokoh-tokoh dalam cerita pada masa itu sudah berjuang dengan problema de- wa-dewa yang merupakan sentuhan dunia personal. Dewa-dewa berperilaku sangat manusiawi. Mereka melakukan berbagai hal yang menjengkelkan manusia, antara lain berzinah dan membunuh.

Mitos-mitos itu biasanya dijelaskan dalam tiga cara sebagai berikut. Pertama, mitos itu merupakan alegori atau kiasan yang disusun oleh para pujangga tentang perjuangan sekian banyak unsur-unsur atau lambang-lambang berbagai bakat dan watak manusia seperti rasio, kebodohan, cinta, dan lain-lain. Bentuk kiasan semacam itu memiliki landasan dalam kenyataan, bahwa beberapa dewa tidak dapat dipungkiri lagi ada kaitannya dengan segi-segi tertentu dengan alam atau sifat-sifat dan kegiatan manusia. Kedua, mitos adalah cerita tentang raja-raja dengan kekuasaan besar dan kebijaksanaan tinggi yang hidup di zaman kuno sekali, kemudian didewakan oleh anak cucu. Ketiga, mitos itu hasil penipuan para imam dan raja, yang dengan cara itu mereka menciptakan suatu posisi legitimasi kekuasaan bagi diri mereka sendiri. Mitos digunakan untuk mengukuhkan legitimasi kekuasaan mereka.

Cassirer (1987: 109-129) menyatakan bahwa mitos erat kaitannya dengan imajinasi mitis yang senantiasa melibatkan tindakan percaya. Tanpa kepercayaan, bahwa obyeknya nyata, maka mitos kehilangan dasar-dasarnya. Kondisi intrinsik dan niscaya ini mendorong orang kepada kutub yang berlawanan. Artinya harus dipertimbangkan pemikiran mitis dengan pemikiran ilmiah. Tentu saja keduanya menempuh jalur berbeda. Namun tampak, bahwa keduanya mempersoalkan hal yang sama, yakni realitas. Durkheim (dalam van Baal, 1987: 29) menyatakan, bahwa model sejati mitos bukanlah alam, melainkan masyarakat. Semua motif dasar yang ada pada mitos adalah proyeksi kehidupan sosial manusia. Proyeksi ini menyebabkan alam menjadi representasi dari dunia sosial.

Muljono (1989:166-167) berpendapat bahwa yang disebut dengan mitos kuno tradisional, secara singkat dapat diuraikan sebagai berikut. Kesusastraan pewayangan yang merupakan kitab-kitab kepustakaan pewayangan yang berisi dongeng, cerita kepahlawanan, analisis tentang pewayangan yang diwariskan secara turun-temurun, akhirnya menjadi mitos kuno tradisional. Komunitas Jawa menganggap rasio dan mitos tidak bertolak belakang, melainkan berjalan berdampingan karena memang ada mitos yang memiliki unsur-unsur kebenaran. Oleh karena itu mitos dapat dipergunakan untuk mengemukakan asumsi-asumsi tentang hal-hal kejiwaan dan rohaniah. Mitos merupakan sumber penting bagi informasi pemikiran manusia yang menyerap nilai-nilai yang diyakini oleh sebuah komunitas, yakni nilai-nilai yang berada di balik imaji-imaji dan simbol-simbol dalam cerita. Cerita dalam mitos dipercaya, bahkan diyakini memiliki kadar keluhuran tinggi.

Hazim Amir (1991: 97-124) menyatakan bahwa keluhu- 
ran nilai-nilai yang dikandung pewayangan itu adalah sebagai berikut.

1. Nilai kesempurnaan sejati, suatu nilai yang mengajarkan manusia bagaimana seharusnya hidup, bahwa sebagai pribadi, makhluk sosial, dan ketuhanan, manusia memiliki tingkah laku dan hidup yang sempurna dan menerapkan ajaran-ajaran kebenaran yang sempurna. Protagonis yang menjalankan nilai-nilai ini di dalam wayang adalah Arjuna dalam lakon Arjuna Sasrabahu.

Nilai-nilai kesempurnaan sejati menurunkan watak-watak kepemimpinan berlandaskan ajaran Hasta Brata, yakni ajaran tentang sikap-sikap sebagai berikut.

a. Setia memberi kebutuhan-kebutuhan hidup siapa saja, sabar.

b. Senantiasa turun kepada rakyat, artinya merakyat, dan memberikan kesejukan dan ketentraman

c. Adil di manapun ia berada

d. Memberi penerangan yang sejuk, harapan, dan kebahagiaan

e. Menjadi sumber petunjuk dalam kehidupan

f. Memiliki pengetahuan yang luas, memiliki kasih sayang dan kesabaran yang tidak terbatas

g. Kukuh-kuat dalam melindungi rakyat

h. Mampu memberantas kejahatan

Daniel Morin (2014: 139) menambahkan bahwa ajaran Hastabrata adalah etika kepemimpinan yang mengajarkan kepada setiap orang supaya hendaknya memiliki delapan watak atau sifat keutamaan yang seirama dengan alam.

Selain itu, Arjuna juga merupakan lambang sikap yang suka melindungi dan berkorban, prihatin. Di samping Arjuna ada Semar dan anak-anaknya, yaitu Gareng, Petruk, dan Bagong sebagai lambang rakyat yang ideal. Arjuna dan Semar adalah satu kesatuan. Menurut Sri Muljono (1978: 69) mereka melambangkan nilai-nilai kesatuan sejati yang mengajarkan manusia menjunjung tinggi kebenaran dan keadilan, hidup rukun gotong royong dalam bermasyarakat dan bernegara, sebagaimana dilambangkan oleh dharma para panakawan, yakni

a. menjadi penasehat atau cahaya penuntun bagi ksatria yang sedang dalam kesulitan, kebimbangan, atau kegelapan

b. menjadi pemberi semangat ketika satria sedang dalam keadaan putus asa

c. menjadi penyelamat sewaktu satria dalam bahaya

d. menjadi penjaga atau pencegah ketika satria dalam keadaan kritis

e. menjadi teman sewaktu satria dalam kesepian

f. menjadi penyembuh ketika satria dalam keadaan sakit

g. menjadi penghibur sewaktu satria dalam keadaan susah

Selain itu, panakawan juga merupakan lambang sikap menjadi pamong, tahu membawakan dirinya dengan jalan berpikir, berbicara, dan bertindak bersih, menolak keangkaramurkaan, menekankan keikhlasan. Lebih jauh lagi, panakawan merupakan lambang sikap pribadi yang berbudi pekerti luhur, membela kebenaran dan rela berkorban. Mereka tanpa harus marah mampu meredakan kemarahan orang lain, suka menenangkan, tidak pernah melukai perasaan orang lain, tidak menyombongkan diri, hidup sederhana, rela berkorban, tidak berlebihan, memperjuangkan cita-cita dengan gigih.

\section{Nilai-nilai kesatuan sejati}

Nilai-nilai kesempurnaan sejati memiliki kesatuan yang bulat dan tidak dapat dipisahkan dari nilai-nilai kesatuan sejati, artinya masing-masing nilai mengandung dan diwarnai oleh nilai yang lain. Oleh karena itu, nilai kesatuan sejati mengandung nilai-nilai: kebenaran, kesucian, keadilan, kebijaksanaan, kekuasaan, kasih sayang, bertanggung jawab.

Nilai-nilai kesatuan sejati membentuk pemimpin yang berwatak menyatukan artinya menjadi pemimpin pemersatu, yakni pemimpin yang disebut berbudi bawa leksana, mewayu hayuning bawana, ambrasta dur angkara. Oleh karena itu terciptalah suatu kehidupan bermasyarakat dalam negara yang tata tentrem kertaraharja, kehidupan demokrasi.

\section{Nilai-nilai kesucian sejati}

Nilai-nilai kesempurnaan sejati dan nilai-nilai kesatuan sejati merupakan kesatuan yang bulat tidak dapat dipisahkan dengan nilai-nilai kesucian sejati. Masing-masing nilai mengandung dan diwarnai nilai-nilai lainnya. Oleh karena itu, nilai-nilai kesucian sejati mengandung nilai-nilai kesederhanaan, kebersahajaan, tidak kongkalikong, tidak munafik, tidak hipokrit, tanpa pamrih. Nilai-nilai kesucian membentuk manusia suci, yaitu manusia yang memiliki tingkah laku yang suci. Nilai-nilai kesucian sejati menciptakan kehidupan masyarakat dan negara yang suci. Adalah amat sulit menjadi manusia yang suci ini. Manusia memiliki nafsu-nafsu rendah yang tidak menuntun kepada kebenaran, melainkan cenderung mendorong berbuat tidak suci, seperti menipu, serakah, angkara murka, suka merebut hak-hak orang lain.

\section{KOMEDI PARODI}

Barnet (1958: 67) menyatakan bahwa komedi menjunjung tinggi atau menghormati nilai-nilai luhur dan norma-norma yang berlaku dalam masyarakat. Komedi mengobati orang dari penyakit bodoh dan keji dengan cara mempergelarkan kebodohan dan kekejian itu di atas panggung. Sementara Meredith (dalam Felheim, 1962: 117) memberi istilah komedi itu sebagai pedang akal sehat. Meredith menyebut komedi sebagai malaikat pelindung atau benteng masyarakat karena tugas drama komedi adalah berusaha mengoreksi etika dan nilai-nilai kehidupan manusia yang menyimpang melalui kegembiraan dan pecip- 
taan hal-hal lucu.

Sementara ironi, kata Muecke (1982: 17- 35) adalah perluasan dari bahasa kiasan. Ironi dalam bahasa kiasan didefinisikan sebagai perkataan yang bertentangan dengan maknanya, artinya mengatakan sesuatu hal, tetapi artinya lain, seperti menyindir dan mengejek. Ciri-ciri dasar ironi adalah kontras di antara apa yang dikatakan dengan apa yang dilakukan, dan hal itu merupakan sesuatu yang keliru. Kontras itu dapat berwujud oposisi, kontradiksi, pertentangan, keanehan, artinya tidak lazim atau tidak sesuai. Ironi adalah bentuk paradoks dan paradoks adalah conditio sine qua non dari ironi.

Selanjutnya Muecke (1982: 17-35) menyatakan bahwa dalam penerapannya, ironi dapat menggunakan strategi satire untuk menemukan atau menciptakan karakter atau penokohan yang janggal, artinya penokohan yang tidak pada tempatnya, atau tidak pantas untuk dijadikan tauladan atau panutan. Ironi seringkali menunjukkan adegan komik atau lucu, bahkan kadang-kadang parodi. Adegan tersebut menampilkan karakter atau penokohan yang kehilangan kepribadian. Tokoh-tokoh tersebut penuh muslihat, penuh penipuan, dan kecurangan. Tokoh-tokoh itu adalah tokoh publik, yakni para bangsawan dan orangorang berkedudukan terhormat yang terperangkap dalam kedok atau topeng, kemudian melakukan penyamaran atau muslihat yang bertujuan ingin mendapatkan pengaruh dan kekuasaan walaupun usahanya itu didasari sifat egois, sifat mementingkan diri sendiri dalam kehidupan sehari-hari.

Istilah parodi, biasanya istilah ini dihubungkan dengan tokoh, yakni tokoh parodi. Menurut Teeuw (1984: 214) tokoh parodi ialah tokoh-tokoh yang diambil dari karya sastra yang secara berwibawa mewakili norma-norma tertentu, kemudian dipermain-mainkan dan ditertawakan. Sebuah parodi meniadakan norma sastra, konteks, dan horizon harapan pembaca atau penonton dengan cara mempermainkan atau menertawakan karya sastra yang sudah ada sebelumnya dan secara berwibawa memiliki norma-norma tertentu.

Tokoh parodi, biasanya dikaitkan dengan tokoh karikatur dan tokoh alegoris, yaitu tokoh kiasan dari tokoh yang ada di tengah masyarakat. Winjana (1998) menyatakan, bahwa kata karikatural dilekatkan pada tokoh tiruan melalui penyimpangan atau distorsi untuk memberikan persepsi tertentu kepada pembaca, sehingga seringkali disebut portrait caricature. Kata karikatur (caricature) artinya memberikan muatan atau beban tambahan. Adapun yang direka ialah tokoh-tokoh politik atau orang yang karena peristiwa penting tertentu menjadi pusat perhatian, atau tokoh-tokoh yang mempunyai kedudukan terhormat. Informasi tentang tokoh-tokoh itu tidak selamanya dimaksudkan sebagai sindiran, melainkan dapat juga hanya untuk menampilkan karya secara humoristis.
Maksud istilah parodi mitos dalam kajian ini adalah kritik, sindiran, dan ejekan yang menimbulkan gelak tawa dan senyuman. Kritik dan sindiran terhadap nilai-nilai luhur, moral adiluhung, norma-norma, dan etika kepantasan yang berada di balik mitos tokoh-tokoh wayang yang melestarikan simbol pemimpin yang sempurna, yang menjalankan tugas mewayuhayuning bawana, artinya memperindah kehidupan berbangsa dan bernegara, ambrasta dur angkara, artinya memberantas kejahatan, memelihara mitos manunggaling kawula-Gusti sebagai simbol demokrasi, sehingga kehidupan masyarakat menjadi tata tenrem kartarajarja.

\section{PARODI MITOS DALAM DRAMA KB DAN SG}

\section{Drama KB}

Drama KB tampak menonjolkan ciri-ciri penokohan parodi, yaitu dengan cara mendistorsikan tokoh-tokoh yang diambil dari lakon wayang, kemudian muncul pemandangan-pemandangan lucu yang menimbulkan gelak tawa. Hardjowirogo (1982: 239-240) menyatakan bahwa dalam lakon wayang, Burisrawa adalah putra raja Salya, raja negara Mandraka. Burisrawa bermuka raksasa, karena ia memang keturunan raksasa. Kakeknya adalah Begawan Bagaspati, seorang pendeta raksasa. Burisrawa disebut juga sebagai satria Madyapura yang bertabiat kasar dan suka tertawa. Ia jatuh cinta pada Sumbadra. Ia bersumpah tidak akan kawin dengan wanita lain kecuali dengan Sumbadra. Sampai meninggal, Burisrawa tidak pernah mempunyai istri. Ia terus-menerus tergila-gila hanya kepada Sumbadra. Namun drama KB menunjukkan Burisrawa bukanlah satria kerajaan Madyapura yang menunggu tahta warisan ayahnya, melainkan seorang konglomerat yang kaya raya, bahkan melebihi kekayaan ayahnya. Meskipun hampir semua jenis perusahaan dimiliki, tetapi hati Burisrawa belum merasa puas karena belum mampu menaklukkan hati Sumbadra. Oleh karena itu Burisrawa selalu mencari siasat bagaimana agar Sumbadra bersedia menjadi istrinya. Burisrawa berwatak kasar dan suka menghalalkan segala cara dalam mewujudkan keinginan-keinginannya. Burisrawa tidak segan-segan menggusur tanah pertanian yang subur hanya untuk mendirikan lapangan golf. Hal itu dilakukan Burisrawa untuk menunjukkan bahwa ia adalah konglomerat yang kaya raya.

Togog : Tapi ini daerah pertanian paling subur di Madyapura.

Burisrawa : Justru karena itu. Masak aku harus mengalah? Ambil planning tata kota yang lama. Ubah. Katakan kepada masyarakat yang tergusur itu, bahwa daerah ini nantinya akan dijadikan cagar budaya, atau apa, kan bisa bikin sejuta alasan yang sulit dibantah. (KB, h. 42)

Sementara Hardjowirogo (1982: 195-196) menyatakan bahwa dalam lakon wayang kulit Sumbadra Larung, Sum- 
badra adalah putri Prabu Basudewa. Ia adalah titisan Dewi Sri, yaitu dewi imbangan dewa Wisnu. Sumbadra disamakan dengan bidadari karena ia terkenal lebih cantik daripada putri-putri cantik lainnya. Sumbadra berwatak sabar. Kalaupun marah, ia memperlihatkan senyum yang manis. Sumbadra mempunyai suami Arjuna dan hidup rukun damai, sehingga kehidupan mereka diibaratkan sebagai ikan mimi dan mintuna, yaitu sejenis ikan laut jantan dan betina yang tidak pernah berpisah.

Drama KB semula menunjukkan Sumbadra berwatak setia dan penyabar, meskipun ditinggal suaminya seminar berbulan-bulan lamanya, Sumbadra tetap sabar menunggu dan tidak marah. Sementara Srikandi, salah seorang istri Arjuna yang lain, sudah tidak sabaran dan marah-marah ditinggal suami berbulan-bulan lamanya, maka Srikandi membuat rujak yang pedas sekali dengan cabai sebanyak lima kilo. Srikandi dalam kemarahannya juga melepas burung-burung peliharaan Arjuna (KB, h. 13). Namun Sumbadra menerangkan dengan sabar kepada Srikandi, bahwa suaminya itu adalah satria utama yang menyebarkan ilmu kepada siapa saja yang membutuhkannya. Sumbadra mengutip ajaran Hasta Brata yang diwejangkan Sri Rama kepada Gunawan Wibisana, sehingga Srikandi menjadi benar-benar tenteram dan reda kemarahannya (KB, h. 14$15)$.

Sumbadra masih tetap sabar dan setia ketika Burisrawa datang merayunya seraya menjelek-jelekkan Arjuna. Burisrawa mendesakkan niatnya mengambil Sumbadra sebagai permaisuri sambil menyuruh Sumbadra meninggalkan Arjuna yang bermuka pucat dan memiliki banyak istri. Sumbadra menjawab dengan tenang, sudah menjadi kewajiban seorang istri untuk tetap ikut suami, walau seburuk apapun watak sang suami, sebab ikatan perkawinan telah mengukuhkan tanda janji setia itu. Suatu pandangan hidup istri-istri yang dianggap tradisional.

Burisrawa : Itu kuno. Menghina derajat wanita. Ya, ampun, kalau watak sang suami buruk dan tidak bisa diubah lagi dengan cara apapun, tinggalkan! Jangan pertahankan rumah tangga yang sudah sefihak itu. Biar kita ini wayang, dinda tapi ya, mbok ya punya karakter, gitu lho.

Sumbadra : Biarlah aku disebut kuno. Tapi kesetianku tidak goyah. Cuma kanda Arjuna suamiku, sampai mati ia tetap suamiku (KB, h. 33)

Lakon wayang Sumbadra Larung menggambarkan tokoh Sumbadra sebagai simbol nilai-nilai kepasrahan dan kesetiaan kepada suaminya, yaitu Arjuna. Nilai-nilai itu dipertahankan Sumbadra walaupun taruhannya harus mati ditikam keris Burisrawa. Kegigihan Sumbadra mempertahankan nilai-nilai luhur itu mendorong dewa-dewa menghidupkannya kembali. Lakon wayang kulit Sumbadra Larung menyimpulkan, bahwa nilai-nilai luhur kepasrahan dan kesetiaan itu tidak pernah mati.
Sementara drama KB menunjukkan Burisrawa hampir putus asa. Burisrawa mengancam sambil menghunus kerisnya, dan berkata bersedia menyerahkan seluruh harta kekayaannya yang tidak akan habis dipakai untuk menghidupi tujuh keturunan. Sumbadra ditusuk keris Burisrawa dan mati. Akan tetapi kemudian hidup lagi dan sudah menjadi Sumbadra yang lain, wanita yang sudah tidak setia lagi kepada Arjuna, melainkan wanita yang sudah terkena bujuk rayu harta kekayaan Buris rawa.

Sumbadra : Baru aku alami peristiwa seperti ini. Seorang lelaki jelek, gendeng, dan nekad lantaran cinta. Dibanding kanda Arjuna, cinta Burisrawa sebenarnya jauh lebih jujur. Boleh dibilang nilainya 24 karat ...(KB, h. 51)

Drama KB pada dasarnya memang sengaja diciptakan Nano untuk membuat parodi mitos lakon wayang tradisional Sumbadra Larung yang memiliki sifat simbolik menjadi drama komedi-parodi. Hal ini dilakukan karena dalam kenyataan kehidupan sehari-hari tampak pemandangan yang bertentangan dengan moral dan nilai-nilai yang dikandung dalam ajaran Hasta Barata, sehingga tampak ironi yang menimbulkan hal-hal lucu. Drama KB memang bertujuan untuk menyindir kebijakan ekonomi-politik pemerintah Orde Baru dekade 1980-an yang memberi keleluasaan penuh, kekuasaan yang sangat besar kepada konglomerat yang menimbulkan praktek pelaksanaan sistem ekonomi kapitalistik- semu di tengah masyarakat. Para konglomerat pemilik modal kuat berusaha dengan berbagai cara untuk membujuk rayu anggota masyarakat menjadi terpengaruh, kemudian sebagian besar masyarakat tanpa disadari menunjukkan kecenderungan sikap hedonis -materialistis. Artinya, sebagian besar anggota masyarakat mudah diiming-imingi kehidupan mewah, sehingga nilainilai kesabaran dan kesetiaan mereka juga mudah luntur. Konglomerasi memiliki kekuasaan untuk membeli kesetiaan dan kesederhanaan dengan mengenyahkan kesabaran. Orang ingin mencapai sukses secara instanly, artinya dengan cepat dan mudah menjual miliknya yang berharga, mulai dari tanah, pekarangan, rumah, jabatan, sampai kepada kehormatan diri sendiri.

Kehidupan sehari-hari masyarakat pada waktu drama ini diciptakan, yakni pada masa pemerintahan Orde Baru dekade 1980-an sampai penghujung dekade 1990-an, menunjukkan kehidupan ekonomi- politik yang dimonopoli elit pemimpin di sekitar lingkaran Presiden Soeharto. Salah satu contohnya dinyatakan oleh Valina Singka Subekti (1998: 123- 147), bahwa Bambang Trihatmojo dan Probosutedjo adalah anak kandung dan saudara sepupu pemegang kekuasaan tertinggi di negara ini. Usaha mereka besar, bukan rahasia lagi, salah satunya berkat kedudukan mereka yang istimewa tersebut. Kedudukan itu dapat menjadi modal kuat untuk melobi berbagai kepentingan bisnis. Oleh karenanya mudah dipahami manakala dalam waktu amat singkat Bambang Trihatmojo mampu membangun imperium bisnis dan menjadi salah satu 
konglomerat pribumi. Agaknya mudah pula dipahami jika muncul pertanyaan pada banyak kalangan; apakah usahanya yang membesar itu adalah karena kemampuan kewirausahaannya, ataukah lebih banyak karena kedudukannya yang istimewa sebagai orang dekat Presiden Soeharto dan merupakan representasi dominasi negara tempat berkumpulnya konglomerat, birokrat kapitalis, para kapitalis semu (ersatz - capitalism). Pemandangan ini bertentangan dengan demokrasi.

Yoshihara Kunio (1991: 97-99) menggunakan istilah lain untuk menyebut kapitalisme sebagai "kapitalisme konco" (crony capitalist), yakni pengusaha yang memperoleh keuntungan yang sangat besar dari hubungan eratnya dengan Presiden Soeharto, misalnya Liem Swie Liong dan Bob Hasan yang memperoleh sejumlah monopoli dan menikmati hak-hak istimewa dari pemerintahan Orde Baru. Liem Swie Liong terus membangun kerajaan bisnisnya dengan memiliki saham pada perbankan, pabrik baja, perusahaan real estate, semen, kendaraan bermotor, dan perdagangan. Sementara itu Bob Hasan memperoleh konsesi kayu gelondongan, perdagangan di bidang pelayaran, manufaktur dan konstruksi.

Tokoh lainnya dalam drama KB adalah Arjuna. Hardjowirogo (1982: 192-193) menyatakan, bahwa dalam lakon wayang kulit purwa, Arjuna merupakan satria penengah Pandawa. Ia adalah seorang raja yang berkedudukan di kerajaan Madukara. Ia senantiasa berhasil mengalahkan lawan-lawannya. Bahkan dewa-dewa tidak segan-segan meminta bantuan kepada Arjuna bila mereka sedang menghadapi lawan yang tidak bisa dikalahkan. Batara Indra misalnya, meminta bantuan Arjuna untuk mengalahkan Niwatakawaca. Arjuna mengalahkan Niwatakawaca dan mendapat hadiah diangkat menjadi raja Kaendran dan bergelar Prabu Kariti.

Namun di dalam drama KB, Arjuna digambarkan sebagai tokoh parodi yang didistorsikan untuk menimbulkan pemandangan lucu yang menimbulkan tertawa. Arjuna digambarkan suka menelantarkan istri-istrinya dan lebih mementingkan seminar tentang becak berbulan-bulan lamanya, bahkan mengakibatkan kesetiaan Sumbadra menjadi luntur. Berbulan-bulan lamanya seminar tentang becak di negara Atas Angin menyebabkan Arjuna tidak tahu sama sekali, bahwa Sumbadra, istrinya yang cantik itu telah ditusuk keris Burisrawa dan pernah mati sebentar, tapi kemudian hidup lagi dan menjadi permaisuri Burisrawa. Berita ini hampir saja menimbulkan perang besar. Perang itu hampir meletus, tetapi kemudian dicegah Batara Narada, dan tiba-tiba muncul Arjuna.

Arjuna : Tunggu-tunggu. Apa-apaan ini. Kedua pihak bersiap untuk berperang. Kenapa saya tidak diajak? Narada : Siapa satria ini, Badut? Datang-datang kok baca sajak.

Badut : O, satria itu adalah Arjuna. Baru pulang seminar dari Atas Angin. Terlalu kerja keras sampai masuk angin. (Di dada dan punggung Arjuna yang telanjang memang nampak berkas-berkas kerokan danmerah-merah).

Narada $\quad$ : (Kaget) Kamu, cucuku Arjuna? Kok lain ya? Bener ini?

Arjuna : : Benar. Hamba Arjuna, eyang Narada.

Narada : Lalu kenapa baru datang? Seminar apa di Atas Angin?

Arjuna : Seminar tentang becak, eyang. Tapi omong-omong perang ini apa penyebabnya?

Narada : Lho, tidak tahu? Tidak Tahu?

Arjuna : : Sama sekali tidak.

Narada : Wah, Badut. Bagaimana cara menjelaskan kepada satria kesiangan ini?

Badut : Saudara, Arjuna, silahkan pulang ke Madukara. Istri saudara, Sumbadra, nanti akan menjelaskan.

Arjuna : Oo, itu juga baik, saya pulang. Tapi sekali lagi, jangan sampai perang ini dilanjutkan tanpa saya. Saya punya ilmu perang baru yang harus dibuktikan keampuhannya. Permisi. (Memanggil) Becak! Becak! Ke Madukara, Bang! (Pergi) (KB, hal. 63).

Kehadiran Arjuna yang seperti satria kesiangan itu mempertegas parodi-mitos yang menimbulkan pemadangan lucu dan memang dimaksudkan sebagai sindiran. Arjuna sebagai satria yang juga ilmuwan disindir karena hanya mampu membawa persoalan-persoalan rakyat kecil ke dalam forum seminar. Sehabis seminar, persoalan-persoalan rakyat kecil itu tetap saja tidak pernah terpecahkan, apalagi terselesaikan dengan baik.

Drama KB menggunakan kosep penokohan parodi dan metode pertukaran tempat dari drama komedi parodi Barat. Oleh karena itu, drama KB melakukan pertukaran tempat penokohan. Penokohan Arjuna dalam lakon wayang Sembadra Larung adalah hero. Arjuna adalah pemimpin yang mengemban tugas mewayu hayuning bawana, ambrasta dur angkara. Oleh karena itu Arjuna menang dan memiliki Sumbadra. Artinya, lakon wayang Sembadra Larung mempertahankan demokrasi. Namun drama KB menunjukkan Arjuna yang dikalahkan. Arjuna bukan hero. Oleh karenanya kehilangan Sumbadra. Sementara Burisrawa adalah hero, pemenang yang akhirnya memiliki Sumbadra. Artinya, drama KB adalah kiasan praktik penyelenggaraan pemerintahan rezim Orde Baru yang melakukan pembiaran kekuasaan konglomerasi yang bertentangan dengan demokrasi.

\section{Drama SG}

Berikutnya adalah drama SG yang juga menonjolkan penokohan parodi dengan konsep ironi dan metode pertukaran tempat dari drama komedi parodi Barat. Artinya, drama SG menunjukkan tokoh-tokoh yang diambil dari lakon wayang yang memiliki karakter yang khas bersifat 
simbolik, mengandung nilai-nilai tertentu, tetapi penokohan seperti itu bertukar tempat menjadi penokohan parodi. Karakter tokoh-tokoh lakon wayang Semar Gugat dalam drama SG digambarkan bertentangan dengan tujuan untuk menimbulkan pemandangan lucu.

Hardjowirogo (1982: 224-225) menyatakan, bahwa dalam lakon wayang, Semar adalah dewa yang bernama Betara Ismaya, anak sulung Hyang Tunggal. Semar diperintahkan oleh Sang Hyang Wenang supaya tinggal di dunia untuk mengasuh (mengemong) keluarga Pandawa yang merupakan satria keturunan dewa. Sesudah Semar tinggal di dunia, parasnya yang elok berubah menjadi jelek sekali. Kejelekan paras Semar itu menandai dirinya sebagai manusia biasa. Semar berwatak sabar, penyayang, dan tidak pernah merasa susah. Akan tetapi, Semar kalau sudah marah tak ada seorang pun yang bisa mencegahnya, bahkan dewa-dewa sekalipun, bahkan dewa-dewa dianggap lebih rendah daripada telapak kaki Semar. Tanda-tanda yang menunjukkan Semar sedang marah ialah bila air matanya bercucuran dan ingusnya mengalir dengan deras. Lakon Semar Minta Bagus menunjukkan Semar meminta kembali parasnya yang tampan sambil berteriak-teriak di hadapan dewa-dewa di Kahyangan Jonggringsalaka, dan dari pantatnya keluar kentut yang tiada henti-hentinya.

Drama SG menunjukkan watak dan kedudukan Semar di atas didistorsikan menjadi bahan tertawaan. Semar adalah tokoh protagonis. Arjuna yang selama ini menjadi momongan Semar dan selalu meminta pertimbangan jika menemui kesulitan, kali ini menghina dan mempermainkan Semar. Srikandi bersedia menjadi istri Arjuna dengan syarat satria itu bersedia pula menyerahkan kuncung yang ada di kepala Semar sebagai mas kawin.

Semar benar-benar merasa terhina terhadap perlakuan Arjuna yang memotong kuncung di kepalanya hanya untuk memenuhi permintaan mahar Srikandi. Semar ingin menuntut balas penghinaan Arjuna tersebut. Semar kalap mengutus Gatotkaca untuk menantang Arjuna mengadu kesaktian. Semar memiliki senjata andalan, yakni kentut sakti dan sudah terbukti tidak ada yang dapat menandingi kentut itu. Akan tetapi, kentut Semar itu gagal mengalahkan Arjuna karena Batari Durga memberikan Arjuna penangkal kentut Semar, yaitu kesaktian yang bernama Lubang Hitam (The Black-Hole) untuk menyerap dan mementahkan kentut Semar itu.

\section{Durga : (Tertawa keras, mabuk kemenangan).}

Kentut. Itu betul-betul kentut. Kalika, jadi dia itu raja palsu. Dia bukan Sanggadonya, tetapi Semar. Hanya Semar yang punya senjata kentut. Tapi The White Kentuts ternyata cuma Kentuts Biruts. hiii........hiiiii ......hiii! (SG, h. 100)

Lakon wayang Semar Gugat dan Semar Minta Bagus menggambarkan tokoh Semar sebagai simbol kedaulatan rakyat dilecehkan Arjuna dengan cara memegang kuncung yang ada di atas kepala Semar semata-mata hanya untuk menyenangkan hati Srikandi. Semar merasa terbakar hatinya. Ia pergi ke Kahyangan Jonggring Salaka untuk meminta parasnya yang dahulu tampan dikembalikan. Setelah itu Semar menaklukkan kerajaan yang patihnya bernama Desapada. Patih itu disuruh Semar untuk mencuri jimat Kalimasada, sebuah pusaka yang menjadi lambang dasar kejayaan Pandawa. Namun kemudian jimat Kalimasada itu dikembalikan Semar dengan senang hati. Ini artinya, jika lambang kejayaan itu sudah tidak ada lagi, maka hal itu merupakan isyarat bahwa Pandawa akan menemui malapetaka. Oleh karena itu, Kresna menasehati Pendawa agar mengadakan dialog dengan Semar yang memiliki jimat Kalimasada. Lakon wayang di depan menyiratkan makna, bahwa kapan saja aktor-aktor politik melupakan kedaulatan rakyat, maka cepat atau lambat pasti roboh.

Laksono (1985: 27) menegaskan, bahwa Semar adalah paling berkuasa. Ia bersama ketiga anaknya menjadi tempat para ksatria Pendawa mencari nasehat jika ada kesulitan dan selalu menumbuhkan harapan di kalangan Pandawa. Hubungan Semar dengan para satria Pandawa melambangkan demokrasi dalam bentuknya yang paling ideal, perpaduan serasi antara rakyat dan rajanya yang dilestarikan dalam mitos manunggaling kawula-gusti.

Akan tetapi, drama SG bukanlah lakon wayang kulit Semar Gugat dan Semar Minta Bagus. Drama SG menunjukkan bahwa nilai-nilai kesempurnaan sejati yang menurunkan watak-watak kepemimpinan berlandaskan ajaran Hasta Brata itu hanya mitos belaka. Nilai-nilai yang melekat pada penokohan lakon-lakon wayang tesebut dipermainkan dan ditertawakan karena memang dalam kenyataan kehidupan sehari-hari pada kurun waktu dekade 1980-an sampai penghujung dekade 1990-an di bawah pemerintahan rezim Orde Baru menunjukkan pemandangan-pemandangan yang bertentangan. Kedaulatan rakyat tidak diberdayakan secara semestinya. Segala aspek kehidupan dan segala peringkat birokrasi menunjukkan praktek-praktek arogansi kekuasaan yang dilakukan aktor-aktor politik, sehingga saluran aspirasi rakyat menjadi tersumbat. Arogansi kekuasaan itu membekukan semangat partisipatoris rakyat dalam menegakkan seni-sendi kehidupan yang lebih demokratis.

Selain tokoh Arjuna dan Semar yang diparodikan, masih ada lagi tokoh Betara Guru dan Betara Narada yang karakternya didistorsikan pula. Hardjowirogo (1982 : 3536) menyatakan, bahwa dalam lakon wayang Batara Guru diberi kekuasaan Hyang Wenang untuk menguasai alam ini karena kesaktiannya. Betara Guru yang mempunyai nama lain Manikmaya melambangkan kehalusan budi manusia. Namun, pada suatu ketika Batara Guru juga pernah berbuat kesalahan. Lakon Sisikirna menggambarkan ada maling sakti yang menyusup ke dalam istana Astina dan bermaksud berkenalan dengan dewi Dursilawati, pu- 
tri Raja Durjudana. Maling itu tidak bisa dikalahkan oleh dewa sekalipun. Satria yang berhasil menangkap maling itu adalah Caranggana, putra Arjuna. Caranggana meringkus maling itu, yang belakangan diketahui ternyata adalah Batara Guru. Jadi, secara kiasan, hati itu bisa juga menjurus ke arah yang salah.

Drama SG menunjukkan Semar yang merasa terhina atas perlakuan Arjuna yang nota bene adalah momongan-nya itu minta kepada Batara Guru agar parasnya yang dahulu tampan dikembalikan seperti semula. Sebelum itu, Semar berteriak-teriak di Balairung istana dewa-dewa yang sepi itu. Semar yang termasuk dewa yang senior mengeluhkan tugasnya di dunia mengabdi kepada satria yang ternyata hanya mendapat hinaan dan janji kosong belaka. Semar menyindir tugas dewa-dewa di Kahyangan itu jauh lebih enak, nyaman, dan mulia, dan tanggung jawabnya juga tidak begitu berat.

Semar : Kalian enak di sini, jadi birokrat. Nongkrong di langit, memandang ke bumi dengan rasa yakin akan tetap berkuasa sepanjang masa. Muka tetep bagus, duduk di kursi bagus berpakaian bagus, kerja sedikit dan banyak liburnya. Tetapi rezeki jauh lebih gede dari rezeki panakawan. Kalian cuma mencatet - catet laporan.

(SG, h. 55)

Kata-kata Semar di atas sebenarnya merupakan sindiran humoristis yang mengejek para wakil rakyat yang dalam menjalankan tugasnya tidak obahnya dewa-dewa di Kahyangan yang balairungnya selalu sepi karena terlalu banyak libur. Mereka tidak pernah benar-benar terlibat dalam kejadian-kejadian nyata dalam kehidupan masyarakat, melainkan hanya mencatat kejadian-kejadian itu dari kejauhan, sehingga tidak pernah mampu memecahkan masalah secara tuntas. Apalagi masalah peka yang menyangkut tindakan sewenang-wenang dan mau menang sendiri oknum penguasa, sehingga menimbulkan penderitaan rakyat, seperti yang dilakukan Arjuna terhadap Semar.

Arjuna dalam menjalankan kekuasaannya berlaku tidak adil dan sewenang-wenang. Semar mencegah ketidakadilan dan kesewenang-wenangan yang dilakukan Arjuna. Akan tetapi, Semar menderita kekalahan secara memalukan. Nilai-nilai keserasian yang menggambarkan adanya kerja sama, dialog antara pemegang kekuasaan dan lembaga penyalur aspirasi rakyat itu hanya ada sebagai mitos dalam simbolisme lakon wayang, sedangkan dalam kenyataan kehidupan sehari-hari di tengah masyarakat yang ada ialah parodi-mitos, bahwa kedaulatan rakyat telah ditiadakan oleh kekuasaan negara.

Drama komedi parodi KB dan SG adalah representasi semakin membengkaknya fenomena materialisme, konglomerasi, kolusi, korupsi, nepotisme di tengah masyarakat. Selain itu adalah ketidaksesuaian kata dan perbuatan di bidang politik dan ekonomi politik. Demokra- si menuntut keterbukaan dan partisipasi semua lembaga maupun individu dalam masyarakat, tetapi dalam kenyataannya lembaga-lembaga yang menjadi penyalur aspirasi politik masyarakat macet, tidak berfungsi sebagaimana mestinya. Partisipasi politik masyarakat dibekukan oleh elit penguasa yang bertindak sewenang-wenang.

Rezim Orde Baru dekade 1980-an sampai penghujung dekade 1990-an, melakukan pemusatan kekuasaan di tangan Presiden Soeharto. Salah satu contohnya disebutkan oleh Eep Saefulloh Fatah (1998: 52- 84), bahwa Orde Baru selama itu bisa mempertahankan terus-menerus status quo dan hanya melakukan penyesuaian-penyesuaian kebijakan yang sifatnya ad-hoc dan artifisial karena tidak terjadi pergantian kepemimpinan politik dan regenerasi. Orde Baru telah memapankan sebuah model operasi sistem politik yang bertumpu hampir sepenuhnya pada peran presiden. Pada saat yang sama, tidak ada kekuatan politik lain, jangankan DPR sebagai lembaga wakil rakyat, bahkan militer sekalipun tidak bisa membangun hubungan tawar-menawar dengan Presiden Soeharto secara efektif. Akibatnya, gaya sistem politik hampir sepenuhnya merepresentasikan gaya personal kekuasaan Presiden Soeharto, bersifat tertutup dan terasa enigmatig-nya operasi sistem politik. Kekuasaan personal yang kukuh dan tersentralisasi di tangan Presiden Soeharto telah memotong basis-basis pembentukan sistem politik yang demokratis.

Drama SG juga meggunakan kosep penokohan parodi dan metode pertukaran tempat dari drama komedi paodi Barat. Oleh karena itu, Drama SG menukar tempat penokohan lakon wayang Semar Gugat yang simbolik menjadi penokohan parodi. Drama SG menggunakan konsep ironi dan metode pertukaran tempat dari drama komedi parodi Barat. Oleh karena itu, drama SG melakukan pertukaran tempat penokohan. Penokohan Semar dalam lakon wayang Semar Gugat dan Semar Minta Bagus adalah hero. Sementara Arjuna adalah pemimpin yang bersama Semar mengemban tugas mewayu hayuning bawana, ambrasta dur angkara, dan membangun masyarakat tata tentrem kerta raharja, adil demokrasi. Namun drama SG menunjukkan keterbelahan kesatuan Semar dan Arjuna. Semar sendiri terbelah menjadi raja Sanggadonya di kerajaan Sibanuas Estat dan berperang dengan Arjuna. Semar kalah. Kentut sakti Semar gagal mengendalikan nafsu kekuasaan Arjuna. Artinya, lakon wayang Semar Gugat dan Semar minta Bagus mempertahankan demokrasi. Namun drama SG menunjukkan Semar dikalahkan. Semar adalah rakyat yang kehilangan kedaulatan. Sementara Arjuna adalah elit penguasa yang mempertahankan kekuasaan. Artinya, drama SG adalah kiasan praktik penyelenggaraan pemerintahan rezim Orde Baru yang melakukan pembiaran kekuasaan yang bertentangan dengan demokrasi. 


\section{SIMPULAN}

Penokohan drama KB dan SG adalah penokohan parodi yang sumbernya diambil dari lakon wayang Sembadra Larung dan Semar Gugat yang secara berwibawa mewakili norma-norma dan nilai-nilai tertentu, tetapi kemudian dipermainkan dan ditertawakan dengan cara melakukan pertukaran tempat penokohan berikut makna mitos yang melekat pada penokohan tersebut. Penokohan drama KB dan SG adalah peniruan atas tokoh publik atau tokoh politik pada kurun waktu pemerintahan rezim Orde Baru yang kemudian didistorsikan sebagai sindiran humoristis. Tokoh-tokoh yang ada dalam lakon wayang tradisional Sembadra Larung dan Semar Gugat dalam konteks simbol adalah mitos yang memuat nilai-nilai dan ajaran yang dikenal akrab sebagai horizon harapan komunitas Jawa. Tokoh-tokoh wayang yang ada dalam lakon-lakon wayang tradisional melestarikan mitos manunggaling kawula Gusti sebagai simbol demokrasi. Namun drama KB dan SG yang modern menunjukkan pemadangan yang bertentangan dengan demokrasi. Parodi mitos drama KB dan SG adalah horizon penerimaan Nano sebagai individu pengarang drama modern.

\section{DAFTAR RUJUKAN}

Amir, Hazim. 1991. Nilai-nilai Etis dalam Wayang, Jakarta: Pustaka Sinar Harapan

Barnet, Sylvan. 1958. Eight Great Comedies, New York: A Mentor Book

Barthes, Roland. 1981. The Theory of the Text. London: Routledge

Cassirer, Ernst. 1987. Manusia dan Kebudayaan: Sebuah Esai tentang Manusia, di -Indonesia-kan oleh Alois A. Nugroho, Jakarta: P.T. Gramedia

Culler, Jonathan. 1981. The Pursuit of Signs. Semiotics, Literature, Deconstruction, London and Henley: Routledge \& Kegan Paul

Daniel Morin, Lutse Lambert. "Problematika Tugu Yogyakata dari Aspek Fungsi dan Makna," dalam Journal of Urban Society's Ats. Vol. 14 o. 2- Oktober 2014. Yogyakata:Institut Seni Indonesia Yogyakarta

Felheim, Marvin. 1962. Comedy: Play, Theory, and Criticism, Harcourt Brace New York: Harcourt Brace Jovanovich Inc.

Fokkema, D.W. \& Elrud Kunne Ibsch. 1977. Theories of Literature in the Twentieth Century Structuralism-Marxism-Aesthetics of Reception-Semiotics. London: C. Hurst \& Co.
Hardjowirogo. 1982. Sejarah Wayang Purwa. Jakarta : P.N. Balai Pustaka

Isser, Wolfgang. 1983. The Implied Reader: Patterns of Communication in Prose Fiction To Beckett. Baltimore and London: The John Hopkin University Press

Junus, Umar. 1985. Resepsi Sastra. Sebuah Pengantar. Jakarta: P.T. Gramedia

Kunio, Yoshihara. 1991. Kapitalisme Semu Asia Tenggara. Jakarta: LP3ES

Laksono, P.M. 1985. Tradisi dalam Struktur Masyarakat Jawa : Kerajaan dan Pedesaan, Gadjah Mada University Press, Yogyakarta

Meredith, George. 1986. An Essay on Comedy. Baltimore: The John Hopkin University Press

Muecke, D.C. 1982. Ironi and the Ironic. London and New York: Methuen

Muljono, Sri. 1989. Wayang, Asal-usul, Filsafat dan Masa Depannya. Jakarta: Gunung Agung

Riantiarno, N. 1990. Konglomerat Burisrawa. Jakarta: Teater Koma

Riantiarno, N. 1995. Semar Gugat. Yogyakarta: Yayasan Bentang Budaya

Riffaterre, Michael. (1978). Semiotics of Poetry. New York: Indiana University Press

Saefulloh Fatah, Eep "Menimbang Masa Depan Orde Baru: Reformasi atau Mati," dalam Maswadi Rauf (Ed.) 1998. Menimbang Masa Depan Orde Baru. Bandung: Mizan

Singka Subekti, Valina. "Dimensi Ekonomi Politik Krisis Ekonomi Indonesia 1997-1998," dalam Maswadi Rauf (Ed.). 1998. Menimbang Masa Depan Orde Baru. Bandung: Mizan

Surheni. (2015). "Empat Koreografer Minangkabau: Dibaca dalam Teks Matrilineal dan Patrilineal," dalam Journal of Urban Society's Arts. Vol 2 No. 2- Oktober 2015. Yogyakarta: Institut Seni Indonesia Yogyakarta

Teeuw, A. 1984. Sastra dan Ilmu Sastra: Pengantar Teori Sastra. Jakarta: Pustaka Jaya

Teeuw A. 1991. Membaca dan Menilai Sastra. Jakarta: P.T. Gramedia Pustaka Utama 
Winjana, I Dewa Putu. 1995. "Wacana Kartun dalam Bahasa Indonesia," Disertasi Doktor Ilmu Sastra, Universitas Gadjah Mada, Yogyakarta 